ఠ

\title{
Corrigendum
}

Alfieri FM, Riberto M, Gatz LS, et al. Functional mobility and balance in community dwelling elderly submitted to multisensory versus strength exercises. Clin Interv Aging. 2010;5:181-185.

\section{Error in author list}

José Maria Santarém was incorrectly included as an author in "Functional mobility and balance in community dwelling elderly submitted to multisensory versus strength exercises" published in Clinical Interventions in Aging.

Fábio Marcon Alfieri ${ }^{1}$, Marcelo Riberto ${ }^{2}$, Lucila Silveira Gatz ${ }^{3}$, Carla Paschoal Corsi Ribeiro ${ }^{2}$, José Augusto Fernandes Lopes ${ }^{2}$, Linamara Rizzo Battistella ${ }^{2}$

${ }^{1}$ São Paulo Adventist University Center, São Paulo, Brazil; ${ }^{2}$ Institute of Physical Medicine and Rehabilitation Hospital of Clinics of the University of São Paulo, ${ }^{3}$ Degree in Physical Education, São Paulo, Brazil

Clinical Interventions in Aging

\section{Publish your work in this journal}

Clinical Interventions in Aging is an international, peer-reviewed journal focusing on evidence-based reports on the value or lack thereof of treatments intended to prevent or delay the onset of maladaptive correlates of aging in human beings. This journal is indexed on PubMed Central, MedLine, the American Chemical Society's 'Chemical Abstracts Ser- vice' (CAS), Scopus and the Elsevier Bibliographic databases. The manuscript management system is completely online and includes a very quick and fair peer-review system, which is all easy to use. Visit $\mathrm{http}: / / \mathrm{www}$.dovepress.com/testimonials.php to read real quotes from published authors.

Submit your manuscript here: http://www.dovepress.com/clinical-interventions-in-aging-journal

submit your manuscript $\mid$ www.dovepress.com

Dovepress

DOI: 10.2147/CIA.SI 5858
(C) 2010 Alfieri et al, publisher and licensee Dove Medical Press Ltd. This is an Open Access article which permits unrestricted noncommercial use, provided the original work is properly cited. 